\title{
The Intention of Using Cell Phones In Digital Banking Service Base on External Factors and Internal Factors
}

\author{
Winny Puspasari Thamrin ${ }^{1}$, Kristiana Dewayani², Feny Fidyah ${ }^{3}$ \\ ${ }^{123}$ Faculty of Psychology, Gunadarma University, Depok West Java, Indonesia \\ *Corresponding author, e-mail: winny@staff.gunadarma.ac.id
}

\begin{abstract}
The growing of digital services in the world of banking and the use of cellular telephones by customers, banks provide services in the form of phone and SMS banking that makes it easier for customers to transaction. The existence of digital banking makes it easy and saves time in making transactions. The purpose of this study was to examine the intention of using cell phones in digital banking services base on external factors (easiness, benefit, trust and risk) and internal factors (self efficacy and locus of control). This research model is prepared based on the concept of risk perception and behavior. Respondents in this study were 98 respondents that consist of students and employees. The sampling technique is non-random sampling. SEM model analysis techniques (structural equation model) with the help of the Lisrell 8.7 program. The results of this study indicate that the data obtained in accordance with the proposed model for both internal and external factors influence the intention of using cell phones for digital banking services.
\end{abstract}

Keywords: Phone and Online Digital, Intention, Risk Perception, Self Efficacy and Locus of Control.

How to Cite: Thamrin, W. P., Dewayani, K., Fidyah, F. (2020). The Intention Of Using Cell Phones In Digital Banking Service Base On External Factors And Internal Factors. International Journal of Research in Counseling and Education. 4 (1): pp. 55-63, DOI: 10.24036/00201za0002.

\section{Introduction}

The development of digital technology is difficult to separate from human life, so that it becomes a basic need for the general public. The development of digital technology is able to change the habits and perspectives of people in using increasingly sophisticated technology. Increasingly sophisticated technological changes make daily activities easier, but can be a challenge for people who are not open to technological developments. Based on the results of the APJII survey (Indonesian Internet Service Provider Association) shows that every year internet usage is increasing from 1998-2015. Along with the increasing use of the internet, this shows that humans want something that is effective and efficient in getting information and in carrying out their daily activities. People easily access the internet. One of them uses a cell phone, because it can be used anytime and anywhere easily. People can access the internet for personal or business purposes. One of them relates to the use of the internet and cellular telephones which are very influential on digital banking services.

In 2020 the target of Indonesia as the largest digital economy country in Southeast Asia, so that the government focuses on increasing financial inclusion through the digital economy. Digital economy encourages changes in the mindset of people in economic decision making, especially as a result of the development of the internet and the technology of mobile phone devices (mobile communication). Digitalization presents an era of digital economy that is instant, fast and transparent replacing the era of conventional economics. Digital banking is oriented to meet customer needs in utilizing digital technology, both applications, devices as delivery channels that can be accessed anywhere and anywhere. Therefore, many public and private banks have facilitated customers to get the ease and smoothness of transactions so that they no longer need to come to the bank's office. The availability of online banking service (Mobilebanking and SMS-banking) which is a service system that functions to carry out various types of financial transactions that can be accessed directly by customers via cell phone.

The use of online banking is fast and easy to help customers in transactions so that they will feel the benefits and satisfaction in their use. In addition to the convenience and benefits that can be felt directly by 
customers, there are other things, namely how much customer trust in online banking sees negative issues as if hackers were able to retrieve account owner data so that it could harm customers. This is a consideration for customers in the use of cellular telephones in digital banking services, one of which is M-Banking and SMS banking given the differences in risk perceptions felt by customers. Therefore, it can be seen from the presence of external factors such as ease, benefits, trust and risk perception that will influence the intention to continue using cellular phones in digital banking services (CDB). This is in line with several studies on online banking services that develop the concept of the theory of TAM (technology acceptance model) which was first introduced by Davis (1989) who said that the perception of customers on the basis of perceived usefulness and perceived ease of use. Venkatesh, Morris et al (2003) explains that there is an important influence in understanding individual responses in information technology. Where there is confidence in the ability of customers to access the internet for their online banking needs which are developed from the concept of self efficacy from Bandura (1997). In addition there are also internal factors, namely locus of control developed by Rotter (1996), namely the extent to which beliefs in an individual can be stimulated from internal and external things which are known as locus of control.

Ahmad and Gupta (2015) that attitudes toward online banking are determined by several factors including the ease, benefits, security, privacy and perceived risks. Another study conducted by Bhatti (2007); Sadi and Noordin (Ahmad \& Gupta, 2011) stated that there are several factors that influence the use of online banking while usability, ease of use, personal innovation, perceived trust, perceived costs, subjective norms, social influence, self control, perceived control behavior, facilitating conditions. and self efficacy.

Based on the description above, researchers are interested in researching from previous researchers who classify them into two factors, namely external factors, namely perceived ease, perceived benefits, trust and perceived risks. Internal factors are self efficacy and locus of control (internal and external). The hypothesis proposed was intention to use cell phones in the base of digital banking services on external factors and internal factors.

\section{Intention}

Fishbein and Ajzen (1975) proposed a theory of behavior formation that was built with a reciprocal relationship between belief, attitude and intention. Attitude is how one believes, views or evaluates an object. Belief is information that someone has about an object. Furthermore, intention is the intention of individuals to show a behavior.

Fishbein and Ajzen (1975) explain that intention consists of four elements, which consist of behavior, targets that will be subject to behavior, situations where the behavior will be shown and the time the action is shown. Furthermore, Fishbein and Ajzen (1975) propose a theory of reasoned behavior that explains that there are two determinants of the occurrence of intention, namely attitude toward the behavior and subjective norms. Attitude toward the behavior is a person's attitude based on views and evaluations of a behavior, and subjective norms are how a person's perception of an object takes into account the opinions of those who influence him. According to Marakarkandy, Yajnik and Dasgupta (2017) behavioral intention is a measure of the strength a person wants to do. In line with the opinion of Surendran (2012) about behavioral intentions is a measure of one's consideration in using available applications.

Previous opinions also agree with the opinion of Ducey (2013) about behavioral intentions someone will do some behavior. The behavioral intention in this study proposes the intention to share information and intention to use the mobile banking application.

Technology Acceptance Model (TAM)

TAM is based on the Theory of Reasoned Action (TRA) proposed by Ajzen and Fisbein (1980). TRA explains the reactions and perceptions of users of Information Technology (IT), which in turn will influence their attitude towards acceptance of these technologies. The main purpose of TAM is to provide an explanation of the determination of computer acceptance in general, providing an explanation of the behavior or attitudes of users in a population (Davis et.al., 1989).

TAM states that behavioral intension to use is determined by two beliefs, namely: first, perceived usefulness is defined as the extent to which someone believes that using technology can improve their performance in this case mobile banking so that it can facilitate transactions and business activities. Second, perceived ease of use is defined as the extent to which someone is convinced that the use of technology is easy, in this case related to the features provided can facilitate mobile banking users in conducting financial transactions. Venkatesh and Davis (2000) state that TAM is a concept that is considered best in explaining user behavior towards new information technology systems. TAM is the model that is considered most appropriate in explaining how the user accepts a system.

Ajzend an Fishben (1980) first discovered the theory of Technology acceptance model (TAM). This theory explains that a person in doing something is driven by two factors: beliefs and normative beliefs. These factors then encourage someone to have an outcome evaluation and motivation to comply. So that these two things will encourage someone to behave and Subjective Norm. The presence of Attitude and Subjective 
Norms will affect one's attention / focus in the behavior intention. At the end of Behavior Intention will affect a person's behavior.

Davis et.al. (1989) developed TAM to examine the determinant factors of the use of information systems by users. The results of this study indicate that the use of information systems is influenced by interest in the use of information systems, which interest is influenced by perceptions of perceived usefulness and perceptions of ease of use.

The research of Sanjaya (2005) on the Effect of the Benefits and Ease of the Behavior of Students' Behavior in Using the Internet. The results of research show benefits, can affect someone in using the internet, while the ease (Perception of Ease of Use) can not affect someone in using the internet.

In other studies it was revealed that the need to use technology will depend on the level of availability in the use of it. The easier this technology is used, the higher the individual's interest in using it (Khan \& Woosley, 2011). The more difficult this technology is used then the lower the individual's interest to use, also the faster individuals and community groups will adopt it (Venkatesh \& Bala, 2008). Support has been described previously in research using mobile banking. There will be several things that individuals will see in use of features that have been provided by the bank.

\section{Trust}

Trust in technology has often been studied, though not as extensively as interpersonal trust. It is the context of automation and people reliance on automation. Similar to interpersonal trust, there are several theoretical models focused on describing trust in technology and its development. Most of these models are adapting based on models describing interpersonal trust. In line the conceptualization of trust in technology developed by McKnight and Chervany (2001).

Trust is a central aspect in some economic transactions because of the deep human need to understand the social environment, that is, to identify what, when, why, and how other people behave. The lack of trust can prevent consumers from being involved in conducting online transactions, one of which is the use of mobile banking. The belief in technology, especially in mobile banking, is a belief that certain technologies have the necessary attributes as expected in certain situations where negative consequences may occur.

\section{Perceived risk}

Perceived risk is defined as the consumer's perception of uncertainty and the negative consequences that may be received for the use of a product or service. Perceived Risk is one of the important components in information processing carried out by consumers.

The concept of Perceived Risk was introduced, by explaining phenomena in consumer behavior such as information seeking, brand loyalty, and trust in others in purchasing decisions followed by the use of mobile banking. Perceived Risk is associated with choice situations that can potentially result in positive or negative. In consumer behavior, the concept of risk only focuses on potential negative outcomes. This potential negative outcome will be an important difference between the notion of risk in consumer behavior with the understanding of risks used in other disciplines.

\section{Self Efficacy}

Self efficacy was developed by Albert Bandura (1997) based on social cognitive theory. Bandura stated that "self efficacy refers to the ability to organize and execute the courses of action required to produce given attainment". According to Bandura (1999) self efficacy, it is defined as belief in the ability of individuals, to achieve success at a certain level that influences the events in an individual's life (Bandura, 1999). Self efficacy is not related to actual abilities but with beliefs held by individuals. In this context, self efficacy is understood not as a specific domain of cognition, but as a general sense of confidence in the ability of individuals to control various types of environmental demands (Jerusalem \& Mittag, 1999).

In general, self efficacy is understood as a trait, self efficacy can change especially in responding or responding to events experienced by individuals (Jerusalem \& Mittag, 1999). Individuals with self efficacy, are moved to regulate themselves, because individuals are open to something new, one of which is related to the use of technology, to gain new experience in facing increasingly sophisticated technological developments. Individuals who have high self efficacy, have five characteristics, namely setting high targets and tend to choose tasks that are difficult, open and accept challenges, have self motivation, have investment by trying harder to achieve goals, and when facing problems, not easy surrender (Luthans, Youssef, \& Avolio, 2007). Where as a person with low self efficacy considers himself unable to do everything around him. In difficult situations, people with low self efficacy tend to give up easily, while people with high self efficacy will try harder to overcome the challenges. This can be attributed to individuals who use mobile banking related to the features provided by the banking sector which are expected to facilitate banking transactions.

Self-efficacy can develop through the experience of using mobile banking, social modeling when looking at other people using the application, the influence of trusted people, social persuasion, and can also be due to feeling comfortable, accepted (arousal physical and psyhological because by using Mobile banking 
applications can help accelerate financial transactions, therefore self efficacy in this study is a stronger belief in using the features available in the mobile banking application.

\section{Locus of Control (LOC)}

According to Rotter (1966) Locus of control is the highest level at which individuals are able to do their work and their confidence in their success. Locus of control is one of the personality variables, which is defined as the individual's belief in being able to control one's own destiny (Kreitner \& Kinicki, 2005). In line with the opinion of Robbins and Judge (2008) Locus of control is the level at which each person believes in their lives is the determinant of their respective destiny in this case which increases the level of success in using the facilities available in mobile banking.

The locus of control in the individual is divided into two, namely the internal control locus which characterizes whoever is responsible for the business and accounts for what happens in their lives caused by ability and effort. External locus of control that characterizes individuals who trust events and understand outside factors.

Everyone who has an internal locus of control will view the world as something predictable, and individuals who participate in the problem. In individuals who have an external control locus, they will view the world as something that cannot be predicted, as well as achieving goals so that individuals will not have a role in it.

Thus it can be denied that individuals who have external locus of control are identified more relying on their hopes to rely on others and more seeking and choosing to support the profitable ones. Meanwhile individuals who have an internal locus of control are identified more relying on their hopes for themselves and are identified as more favoring skills rather than just being profitable.

\section{Method}

This study consisted of 98 respondents, namely students and employees with non-random sampling technique.

Instrument

The distribution of questionnaires was done by using the help of Google Form by using a bank account and using banking services. Before testing the hypothesis, the measuring instrument is feasibility tested by looking at the validity test and reliability test of the measuring instrument. The validity used is content validity using CFA technique (Confirmatory factor analysis) and convergen validity (AVE). Reliability used is construct reliability (CR).

Self efficacy. Self-efficacy self-measurement instrument which is a self-efficacy scale was prepared based on Bandura (1977) concept which was later developed into self-efficacy in terms of technology use (Taylor \& Tod, 1995), then developed again for this study. Self efficacy instrument consists of 2 items, AVE $=0.6139, \mathrm{CR}$ $=0.7422$.

Locus of Control Scale. Locus of Control Scale, developed from Rotter (1990), This scale consists of 2 internal locus of control items, $\mathrm{AVE}=0.616$, and $\mathrm{CR}=0.763$, and an external locus of control scale consists of 2 items, AVE $=0.623, \mathrm{CR}=0.767$.

Risk perceived questionnaire. This questionnaire measures the perception of the risk of financial services online, developed from Featherman and Pavlou (2003), consisting of 3 items, AVE $==0.5654, \mathrm{CR}=0.7848$

Technology use perception questioner is a tool to measure customer perceptions about using technology for financial services developed by Davis (1989) based on the TAM (Technology Acceptance Model) concept. The questionnaire is divided into two parts, namely the perception of ease of use of CDB. . consists of 2 items, $\mathrm{AVE}=0.767, \mathrm{AVE}=0.861$, and the perception of the benefits of using $\mathrm{CDB}$ consists of 4 items, $\mathrm{AVE}=0.613, \mathrm{CR}$ $=0.864$.

Trust to technology questionnaire. This measuring instrument measures how high the customer's trust in financial transactions developed by Constante, Hartog and Petkovic (2011) is based on the concept of A General Trust Perception Model (GTPM), consisting of 4, AVE $=578, C R=0.845$.

Intention to use scale. This scale measures $C D B$ use intentions repeatedly and the intention to advise others to use CDB. Consisting of 3 items, $\mathrm{AVE}=0.639, \mathrm{CR}=0.842$

\section{Results and Discussion}

\section{Data Analysis}

Respondent data distribution

Data distribution of respondents in terms of gender, level of education, employment status, and amount of salary received each month. 


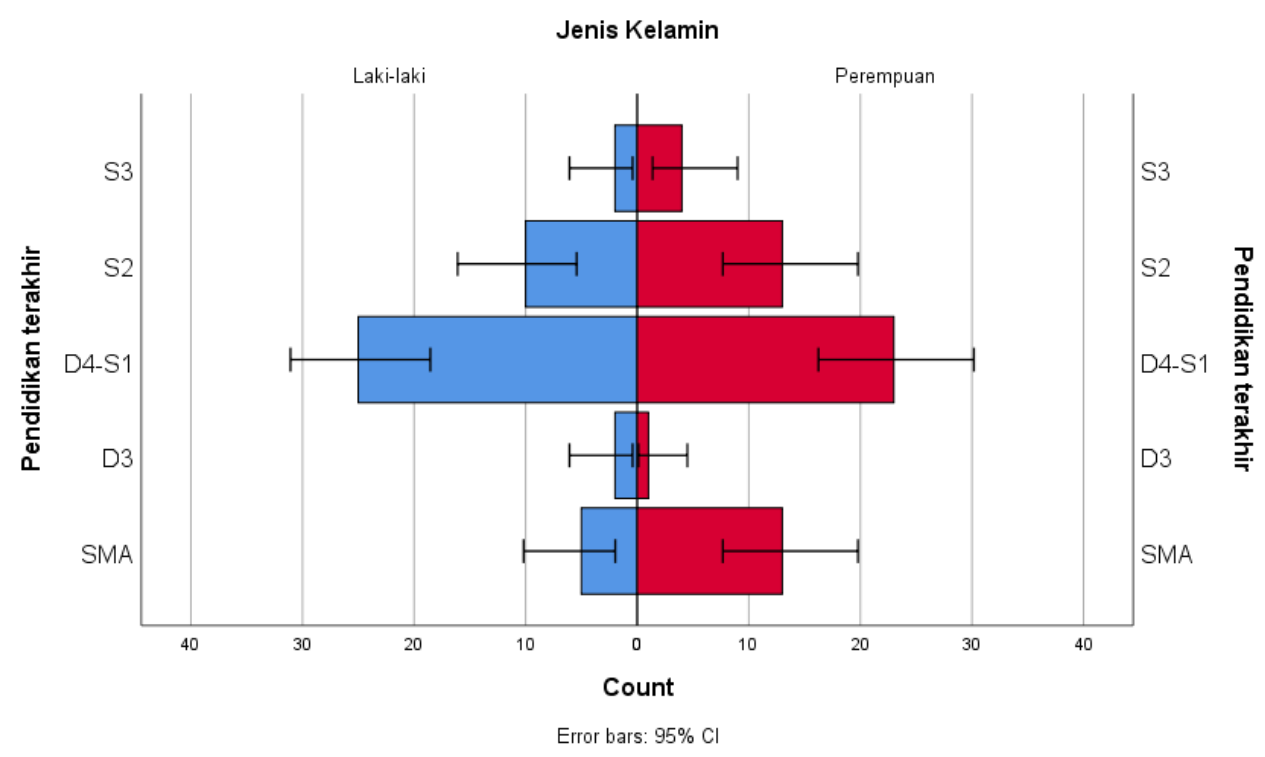

Graph 1: Distribution of Respondents Based on Gender and Last Education

The total number of respondents was 98 people, consisting of $44.9 \%$ male and $55.1 \%$ female.

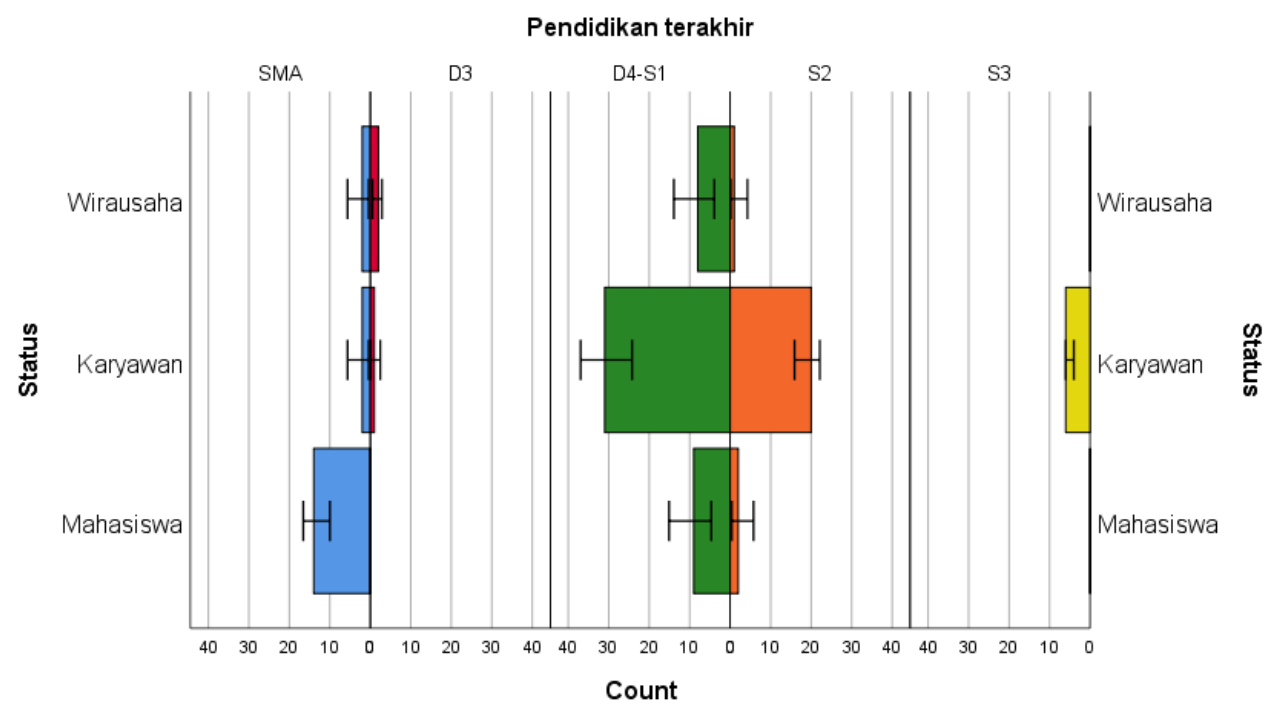

Error bars: $95 \% \mathrm{Cl}$

Graph 2: Distribution of respondents based on recent education and employment status.

If viewed from the level of education, as many as $18.4 \%$ of respondents graduated from high school, $3.1 \%$ from the last education D3, 49\% from the last level of education D4 / S1, and 23.5\% from the last education of S2, while the last education of S3 was $23.5 \%$. Whereas when viewed from the status of employment, the majority of respondents $61.2 \%$ worked as employees in various companies, $25.5 \%$ had a profession as students, and $13.3 \%$ were entrepreneurs. 


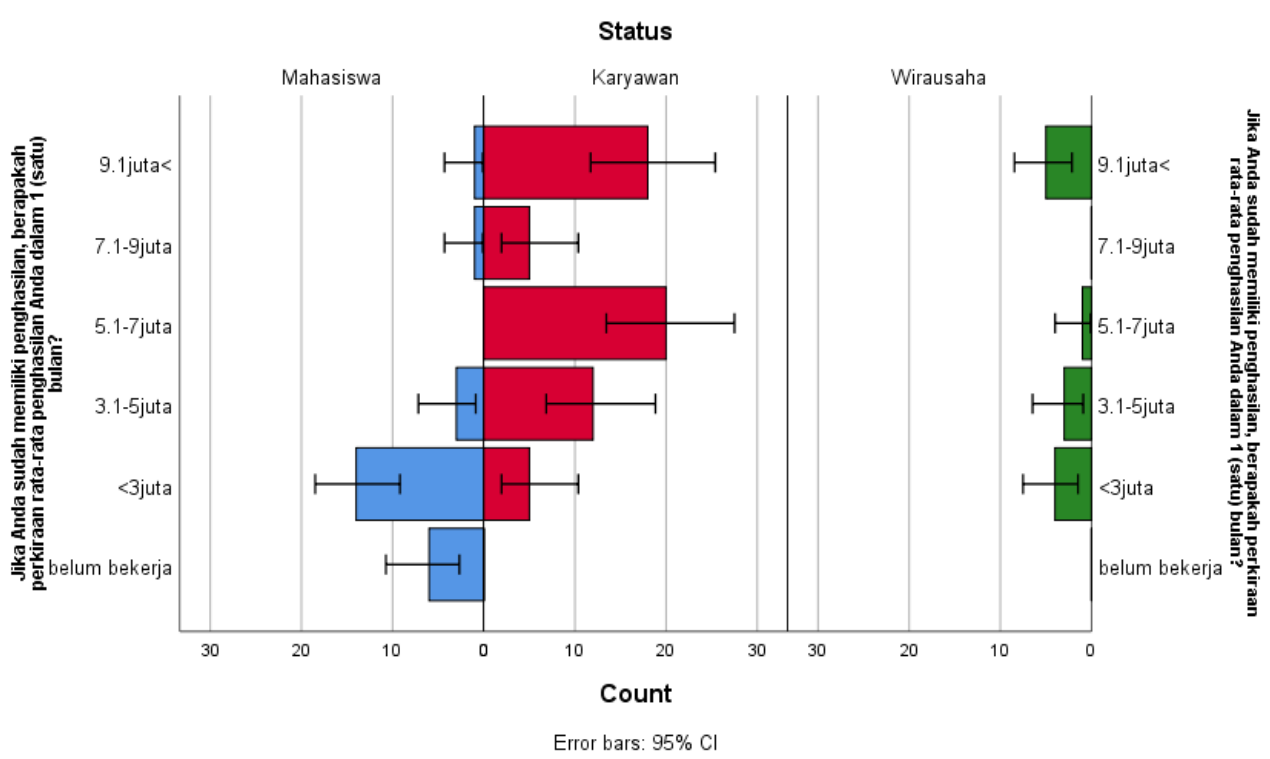

Graph 3: Distribution of respondents based on the amount of salary received per month

In the graph above, despite the status of students, some respondents have earned salaries. The status in question is that currently respondents are officially registered as students, or employees or entrepreneurs, and the data has been sorted out and no respondents answered more than one status option.

\section{Hypothesis testing}

The proposed hypothesis is the intention to use cell phones in the base of digital banking services on external factors and internal factors, and tested for significance using SEM (Structural Equation Model) with Lisrel 8.7 software. The results are :

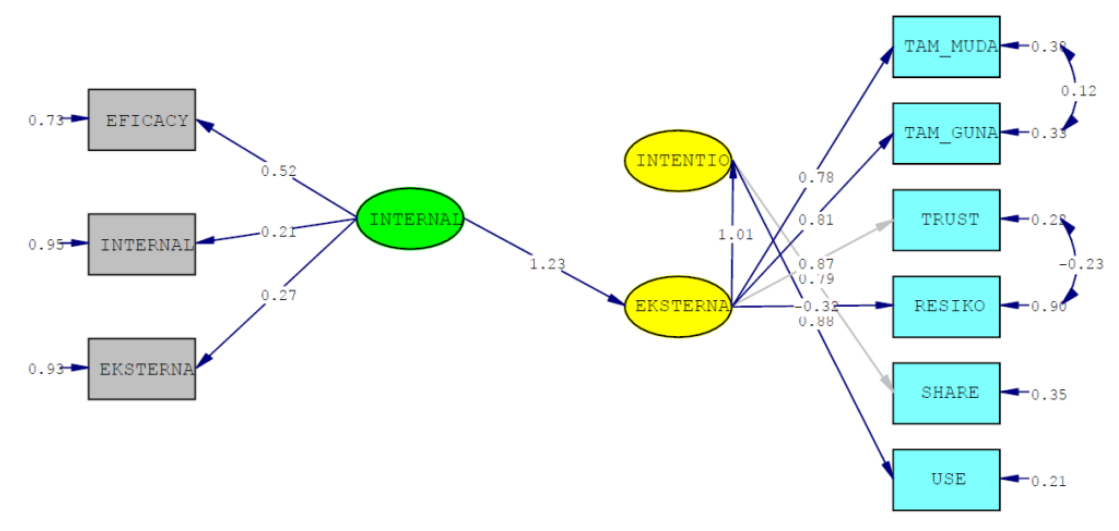

The conceptual model is tested for compatibility with the data and is declared fit, ie between the concept and the data there is a match. this is seen from degrees of freedom $=19$, minimum fit function Chi-Square $=$ 42.83, P-Value for Test of Close Fit $($ RMSEA $<0.05)=0.038$, Normed Fit Index $(\mathrm{NFI})=0.94$, Non-Normed Fit Index $(\mathrm{NNFI})=0.94$, Parsimony Normed Fit Index $(\mathrm{PNFI})=0.50$, Comparative Fit Index $(\mathrm{CFI})=0.97$, Incremental Fit Index $(\mathrm{IFI})=0.97$, Relative Fit Index $(\mathrm{RFI})=0.89$, Root Mean Square Residual $(\mathrm{RMR})=0.048$, Standardized RMR $=0.048$, Goodness of Fit Index $(\mathrm{GFI})=0.92$, Adjusted Goodness of Fit Index $($ AGFI $)=0.81$.

The hypothesis in this study was accepted, namely the intention to use CDB by external factors and internal factors. In this case, external factors as variables that mediate the relationship between internal factors and the intention to use $\mathrm{CDB}$ in more detail can be explained as follows: 

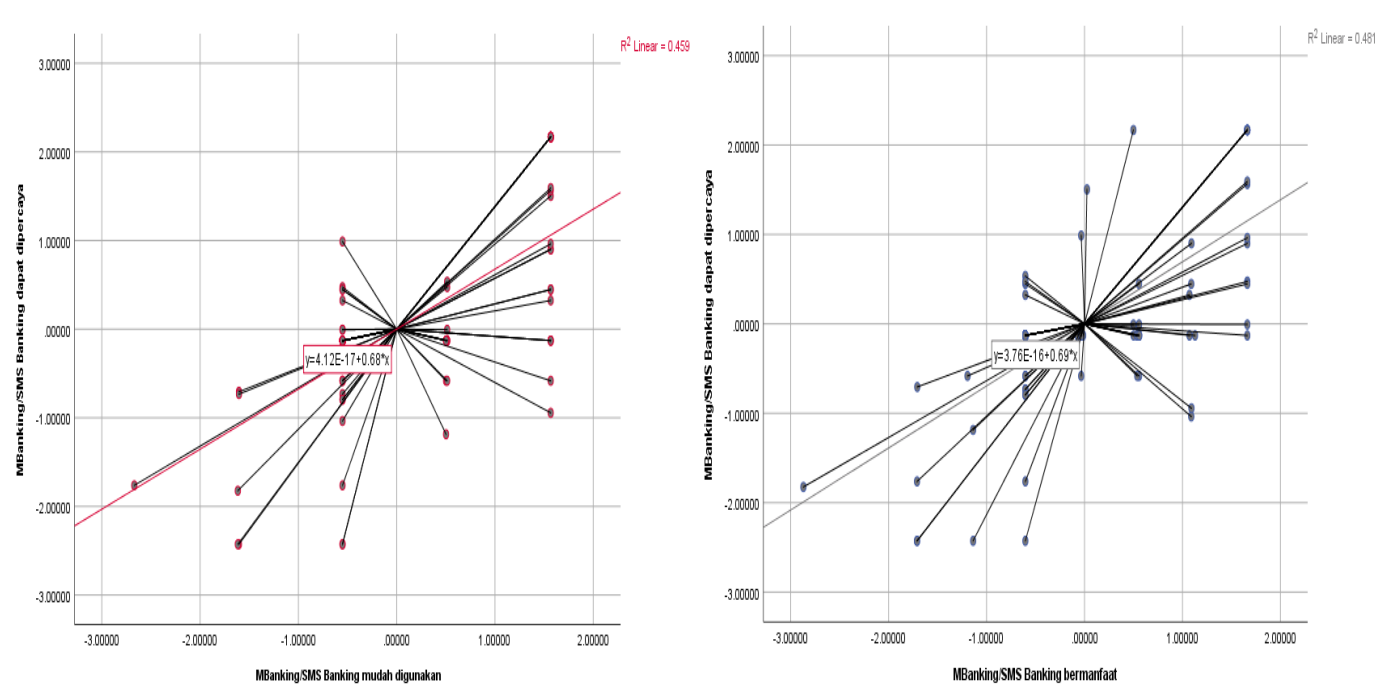

If the respondent feels easy to use $\mathrm{CDB}$, it will be perceived that the use of $\mathrm{CDB}$ can be trusted. Similarly, if you use CDB, it is useful, it will be perceived as trustworthy too.

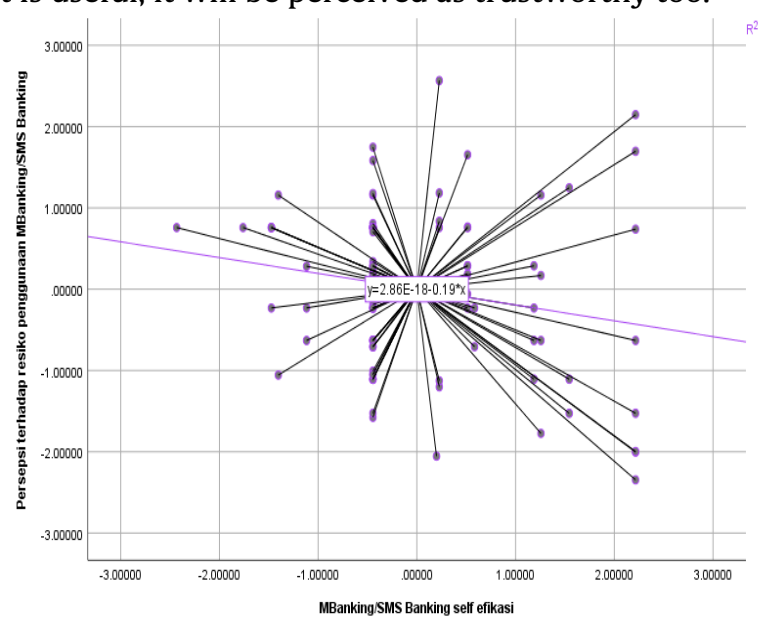

There is a negative correlation of self-efficacy and risk perception, if the respondent is more able to use CDB then the risk perception will be low.
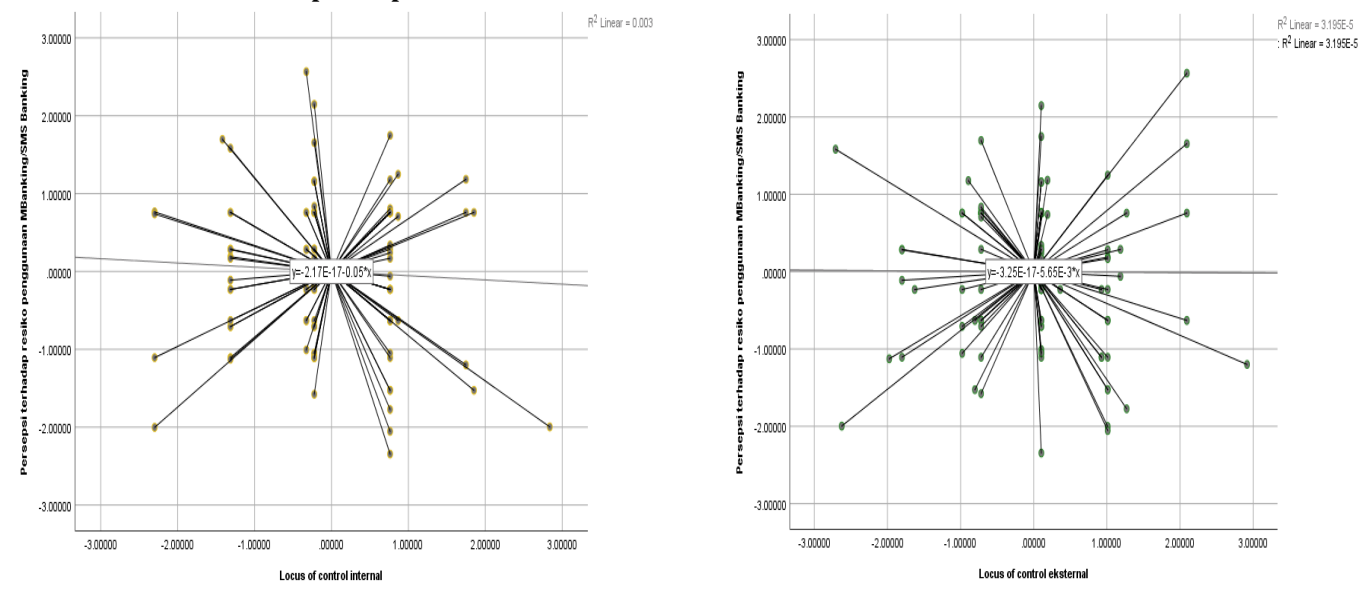

However, both internal and external locus of control do not correlate with risk perception using CDB. 

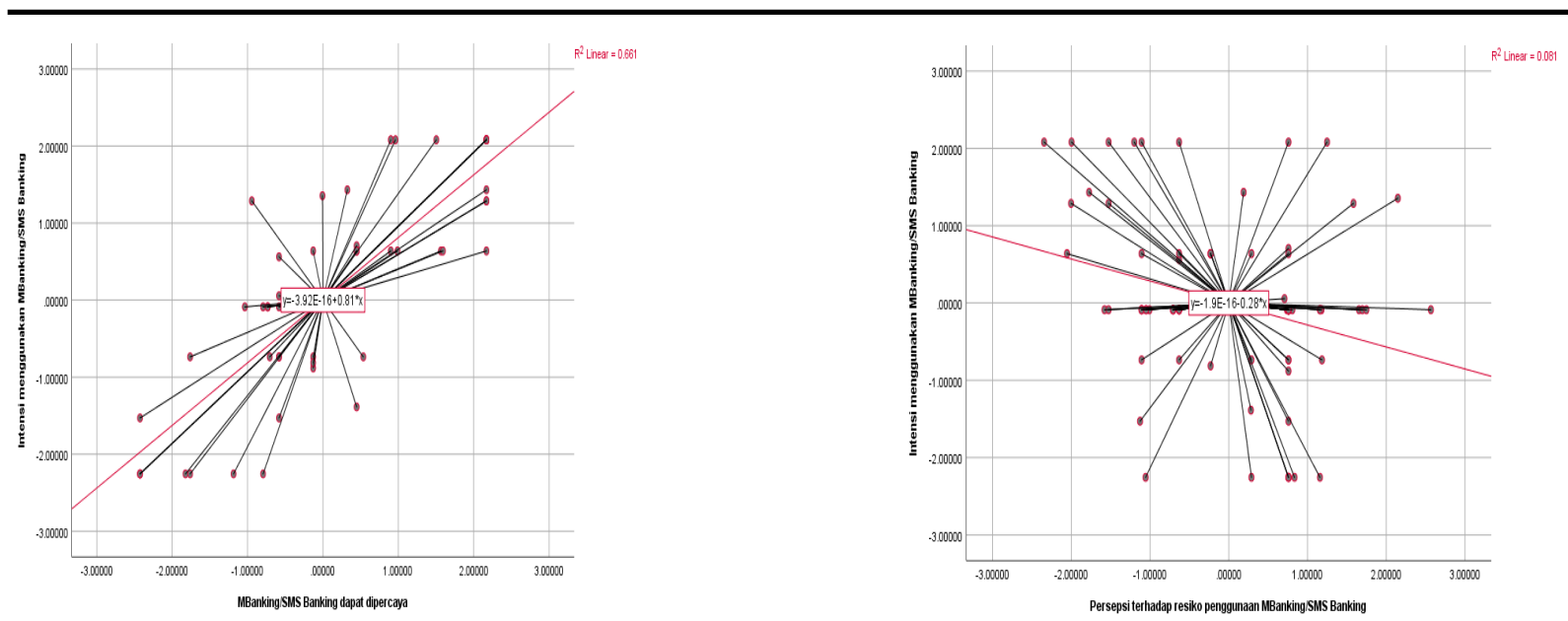

The graph above shows that there is a positive trust correlation and intention to use $\mathrm{CDB}$, and there is a negative correlation of risk perception and intention to use CDB. Thus, the higher risk perception of using $\mathrm{CDB}$ will be followed by the low intention to use $\mathrm{CDB}$.
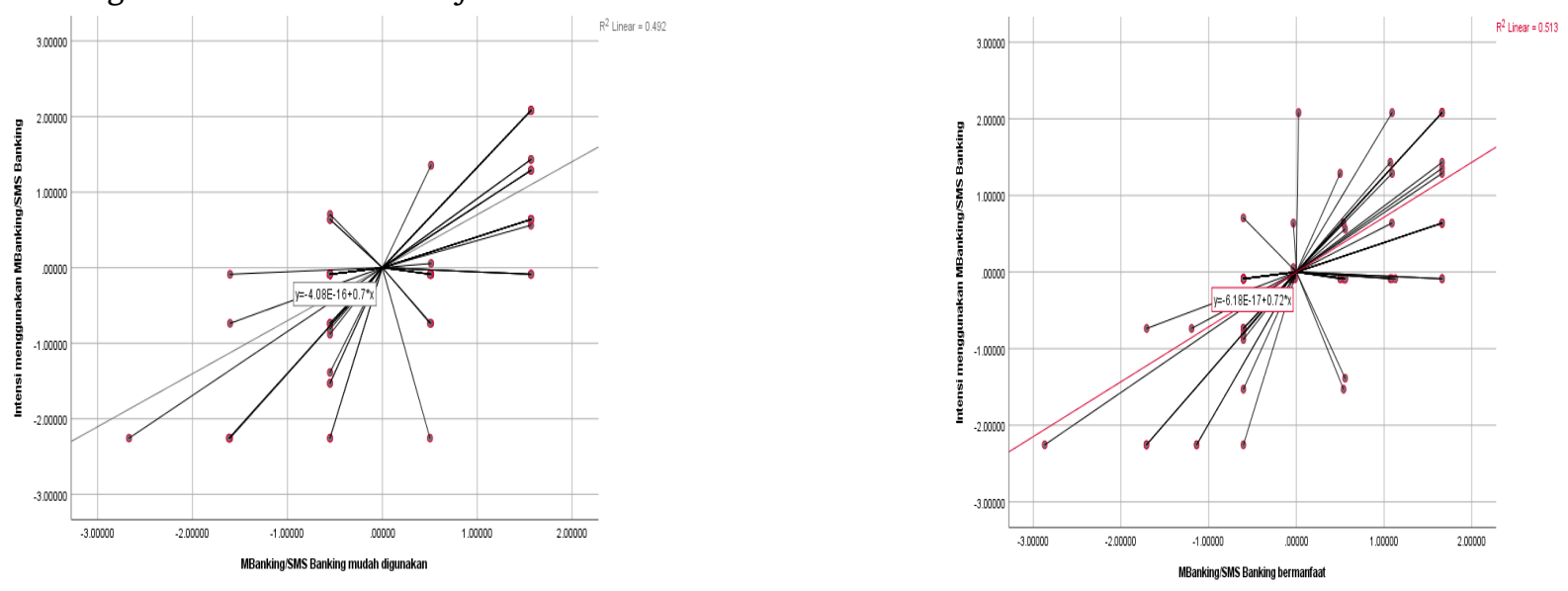

The easier and more useful use of $\mathrm{CDB}$ will be followed by high intention to use CDB Thus, the intention to use $\mathrm{CDB}$ by internal factors and external factors.

\section{Discussion}

This study found that internal factors influencing the intention to use CDB were mediated by external factors, ease of use, usefulness, trust and risk perception. Respondents who have the ability to use CDB and have perceptions of ease, usefulness, trust and do not feel any risk, the respondent will have the intention to keep using CDB and advise others to use CDB.

\section{Conclusion}

The hypothesis in this study is that external factors and internal intention factors to use CDB, and also for others to participate in using CDB in this case are external factors that mediate the relationship of internal factors and the intention to use and use other people to use CDB. Based on demographic data from the area there is no influence on the intention to use $C D B$. Various types of $C D B$ use at the education level are available, this is seen by the higher level of education using SMS- Banking. By sex, there were no significant differences in the intention to use CDB both men and women.

\section{References}

Ajzen, I. and Fishbein, M. (1975). Belief, Attitude, Intention, and Behavior: An Introduction to Theory and Research. MA: Addison-Wesley.

Ajzen, I. And Fishbein, M. (1980). Understanding Attitudes and Predicting Social Behavior. Englewood Cliffs, New Jersey: Prentice Hall.

Bandura, A. (1997). Self efficacy - the exercise of control (fifth printing, 2002). New York: W.H. Freeman \& Company. 
Bandura, A.(1999). Social Cognitive Theory of Personality. New York: Academic Press.

Bhatti, T. (2007). Exploring factors influencing the adoption of mobile commerce. Journal of Internet Banking and Commerce. Vol. 12. pp. $1-13$.

Costante, E., den Hartog, J. I., \& Petkovich, M. (2011). Online trust perception: what really matters. Proceedings of the first workshop on socio-technical aspect in security and trust. Eidhoven University of Technology.

Davis, F. D. (1989). Perceived usefulness, perceived ease of use, and user acceptance of information technology. MIS Quarterly. Vol. 13 No. 3. pp. 319 - 339.

Davis, F.D. (1989). Bagozzi, R.P., Warshaw, P.R. User Acceptance of Computer Technology: A Comparison of Two Theoretical Models. Management Science, 35, 8.

Featherman, M., and Pavlou P. (2003). Predicting e-services adoption: a perceived risk facets perspective. Inj. DeGross (ed.), proceedings of the eighth americas conference on information systems. New York: ACM.

Jerusalem. M \& Mittag, W. (1995) Self-efficacy in stressful life transitions. Self efficacy in Changing Societies. A. Bandura (Ed). New York: Cambridge University Press.

Kreitner. R and Angelo. K. (2005). Orgaizational Behavior. Jakarta: Salemba Empat.

Luthan, F., Youssef, C.M., \& Avolio, B.J. (2007). Psychological Capital: Developing the Human Competitive Edge. NY: Oxford University Pres.

Marakarkandy, B., Yajnik, N., \& Dasgupta, C. (2017). Enabling Internet Banking Adoption: An Empirical Examination With An Augmented Technology Acceptance Model (TAM). Journal of Enterprise Information Management, 302). 263-294.

McKnight, D. H., \& N. L. Chervany. (2001). What Trust Means in E-Commerce Customer Relationship: An Interdisciplinary Conceptual Typology. Journal of Electronic E-Commerce. 6, 2, 35-60.

Robbins. S. P. and Timothy A. Judge. (2008). Perilaku Organisasi Edisi ke-12, Jakarta: Salemba Empat.

Rotter, J.B. (1990). Internal versus external control of reinforcement: a case history of a variable. American Psychologist. Vol. 45, No. 4. pp. $489-493$.

Rotter, J.B. (1966). Generalized expectancies for internal versus external control of reinforcement. PSychological Monographs. Vol. 80. pp. 1 - 28.

Sanjaya, S.I.P. (2005). Pengaruh Rasa Manfaat dan Kemudahan Terhadap Minat Berperilaku. Kinerja. Vol 9 No.2. Hal. 113-122.

Surendran, P. (2012). Technology Acceptance Model: A Survey of Literature. International Journal of Business and Social Research (IJBSR), Volume-2, No.-4.

Taylor, S \& Todd, P. A. (1995). Understanding information technology usage: a test of competing models. Information Systems Research. Vol. 6 No. 2. pp. $144-175$.

Venkatesh, V. (2000). Determinants of Perceived Ease of Use: Integrating Control, Intrinsic Motivation, and Emotion into the Technology Acceptance Model. Information Systems Research, vol. 11, no. 4, pp. 342365.

Venkatesh, V., Morris et al. (2003). User acceptance of information technology: toward a unified view. MIS Quarterly. Vol. 27 No. 3. pp. 425 - 478.

Venkatesh, V. dan H. Bala. (2008). "Technology Acceptance Model 3 and a Research Agenda on Interventions." Decision sciences, 39(2), May. 273- 315. 